\title{
Factors associated with drug shortages in Canada: a retrospective cohort study
}

\author{
Wei Zhang PhD, Daphne P. Guh MSc, Huiying Sun PhD, Larry D. Lynd PhD, Aidan Hollis PhD, \\ Paul Grootendorst PhD, Aslam H. Anis PhD
}

\section{Abstract}

Background: To monitor the magnitude of the drug shortage problem in Canada, since 2017, Health Canada has required manufacturers to report drug shortages. This study aimed to identify the factors associated with drug shortages in Canada.

Methods: We conducted a retrospective cohort study of all prescription drugs available on the market between Mar. 14, 2017, and Sept. 12, 2018, in Canada. All drugs of the same active ingredient, dosage form, route of administration and strength were grouped into a "market." Our main outcome was shortages at the market level, determined using the Drug Shortages Canada database. We used logistic regression to identify associated factors such as market structure, route or dosage form, and Anatomic Therapeutic Chemical (ATC) classification.

Results: Among the 3470 markets included in our analysis, 13.3\% were reported to be in shortage. Markets with a single generic manufacturer were more likely to be in shortage than other markets. Markets with oral nonsolid route or dosage form were more likely to be in shortage than those that were oral solid with regular release (odds ratio [OR] 1.66, 95\% confidence interval [CI] 1.11 to 2.49). Markets for sensory organs were more likely to be in shortage than most other ATC classes. Markets with a higher proportion of drugs covered by public insurance programs were more likely to be in shortage (OR $1.03,95 \% \mathrm{Cl}$ 1.00 to 1.05 per $10 \%$ increase).

Interpretation: Markets with a single generic manufacturer were most likely to be in shortage. To ensure the security of drug supply, governments should be vigilant in monitoring markets with a single generic manufacturer, with complex manufacturing processes, with higher demand from public programs or those that are in certain ATC classes.

hortages of EpiPen for severe allergies, ${ }^{1-3}$ opioid drugs $^{4-6}$ and bupropion for mental illnesses ${ }^{7}$ have recently made headlines in Canada and globally. Such shortages can have severe, even life-threatening, consequences for patients. ${ }^{8}$ For example, shortages in generic intravenous norepinephrine are associated with increased mortality among patients with septic shock. ${ }^{9}$ Opioid shortages increase the risk for medication errors (e.g., delayed time to analgesia, adverse effects) when patients are administered a less familiar alternative, which leads to unnecessary patient suffering and longer hospital stays. ${ }^{4,10}$ In addition, drug shortages can aggravate the stress and burden on physicians and pharmacists and increase labour costs when they have to change their practices because of drug shortages. ${ }^{8,10}$

Empirical studies of the causes of drug shortages have tended to use the longitudinal, high-quality drug shortage data provided by the US Food and Drug Administration ${ }^{11}$ and American Society of Health-System Pharmacists. ${ }^{12}$ These studies have identified manufacturing-quality problems for sterile injectable drugs, ${ }^{13,14}$ declines in the number of suppliers for sterile injectable drugs ${ }^{14}$ and lower drug prices for vaccine and generic drugs ${ }^{15-17}$ as reasons for shortages in the United States.

Empirical evidence from Canada is sparse because of a lack of reliable data on drug shortages. ${ }^{18-21}$ Although Canadian drug manufacturers have voluntarily reported shortage data since 2011, these data were incomplete and unreliable for

Competing interests: Aidan Hollis has received compensation for having provided expert reports relating to patent litigation on behalf of Apotex, Mylan and Pharmascience. Paul Grootendorst has received compensation for expert reports relating to patent litigation on behalf of Apotex and Teva, and reports commissioned by the Canadian Generic Pharmaceutical Association. None of these reports are related to the topic of the paper. All authors report a grant from the Canadian Institutes of Health Research supporting the conduct of the study.

This article has been peer reviewed.

Correspondence to: Wei Zhang, wzhang@cheos.ubc.ca CMAJ Open 2020. DOI:10.9778/cmajo.20200036 
research purposes. On Mar. 14, 2017, manufacturers were required to report timely information on drug shortages to Health Canada. ${ }^{19,21-23}$ In this study, we aimed to identify the major factors associated with drug shortages in Canada using the drug shortage information available after such reporting was mandatory.

\section{Methods}

\section{Study design}

We conducted a retrospective cohort study of all prescription drugs available on the market between Mar. 14, 2017, and Sept. 12, 2018, in Canada.

\section{Data sources}

Manufacturers are required to report drug shortages on the Drug Shortages Canada website. ${ }^{22}$ A shortage is a situation in which a manufacturer is unable to meet the demand for a drug that has been approved in Canada. ${ }^{22}$ The drug shortage database, starting from Mar. 14, 2017 (start of mandatory reporting) to Sept. 12, 2018, was extracted from the website. All ongoing shortages as of Mar. 14, 2017, and all new shortages that occurred during the study period, were included in the study. The database contains information on the package size of each drug identification number (DIN) that was reported in shortage. The DIN uniquely identifies a drug's active ingredients, strength, dosage form, route of administration and manufacturer. More information on the shortage reporting and database, and other data sources (Health Cana- da's Drug Product Database, ${ }^{24}$ Canadian Institute for Health Information $^{25}$ and PharmaClik ${ }^{26}$ ), can be found in Table 1 and Appendix 1, available at www.cmajopen.ca/content/8/3/ E535/suppl/DC1.

\section{Study sample and variables}

Our study sample consisted of all prescription drugs marketed in Canada from Mar. 14, 2017, to Sept. 12, 2018. Each DIN was followed from Mar. 14, 2017 (already marketed) until the last day it was actively marketed during the study period. Following the methods of Danzon and Furukawa ${ }^{27}$ and Dave and colleagues, ${ }^{17}$ we organized DINs of all products with the same active ingredients, dosage form, route of administration and strength into a group and called the group a "market."

The variables extracted from the Drug Shortages Canada website (D.G.), Health Canada's Drug Product Database (D.G.), PharmaClik and the Canadian Institute for Health Information are outlined in Table 1 . The data to identify variables were not extracted from the source databases in duplicate.

\section{Outcomes and factors}

Our focus was on shortages at the market level, which occur when all manufacturers of the same interchangeable drug report shortages. We also evaluated shortages at the DIN level, indicating that some but not all manufacturers of the drug reported a shortage. Furthermore, we calculated the duration of shortages (total number of days in shortage during the study period) at the market and DIN levels.

Table 1: Data sources

\begin{tabular}{|c|c|c|c|}
\hline Database & Data field extracted and used & $\begin{array}{c}\text { Time period or extract } \\
\text { version }\end{array}$ & Source \\
\hline $\begin{array}{l}\text { Drug Shortages } \\
\text { Canada } \\
\text { Database }\end{array}$ & $\begin{array}{l}\text { DIN, }{ }^{*} \text { package size, actual shortage start date, shortage reasons } \\
\text { (shortage of an active ingredient, shortage of an inactive ingredient } \\
\text { or component, disruption of the manufacture of the drug, } \\
\text { requirements related to complying with good manufacturing } \\
\text { practices, delay in shipping of the drug, demand increase for the } \\
\text { drug, or other), estimated shortage end date and actual shortage } \\
\text { end date, if available }\end{array}$ & $\begin{array}{l}\text { Mar. 14, } 2017 \text { to Sept. 12, } \\
2018\end{array}$ & $\begin{array}{l}\text { Drug Shortages } \\
\text { Canada website }\end{array}$ \\
\hline $\begin{array}{l}\text { Drug Product } \\
\text { Database }\end{array}$ & $\begin{array}{l}\text { DIN, drug name, active ingredient(s), strength, dosage form, route } \\
\text { of administration, manufacturer, package size, Active Ingredient } \\
\text { Group number, † Anatomic Therapeutic Chemical classification, } \\
\text { schedule (e.g., prescription, Controlled Drugs and Substances Act, } \\
\text { biological, over-the-counter, "ethical" products } \ddagger) \text {, market status } \\
\text { (marketed, cancelled, dormant) and status date }\end{array}$ & $\begin{array}{l}\text { Data extracted were last } \\
\text { updated by Health Canada } \\
\text { on Apr. } 12,2019\end{array}$ & Health Canada ${ }^{24}$ \\
\hline $\begin{array}{l}\text { Formulary data } \\
\text { for } 9 \text { provinces } \\
\text { in Canada§ }\end{array}$ & $\begin{array}{l}\text { DIN; brand generic code that indicates whether a drug is a brand, } \\
\text { generic or biologic; plan or program; formulary coverage start date } \\
\text { and end date and the listed price, if available }\end{array}$ & April 2008 to Mar. 31, 2017 & $\begin{array}{l}\text { Canadian Institute } \\
\text { for Health } \\
\text { Information }{ }^{25}\end{array}$ \\
\hline PharmaClik & DIN, package size & $\begin{array}{l}\text { Catalogue downloaded on } \\
\text { Oct. } 10,2018\end{array}$ & $\begin{array}{l}\text { McKesson } \\
\text { Canada }^{26}\end{array}$ \\
\hline \multicolumn{4}{|c|}{$\begin{array}{l}\text { Note: DIN = Drug Identification Number. } \\
\text { `DIN uniquely identifies a drug's active ingredients, strength, dosage form, route of administration and manufacturer. } \\
\text { †A 10-digit number that identifies products that have the same active ingredient(s) and ingredient strength(s). } \\
\text { łDrugs that do not require a prescription but are generally prescribed by medical practitioners for unscheduled professional use and emergency use. } \\
\text { §Alberta, British Columbia, Manitoba, New Brunswick, Newfoundland and Labrador, Nova Scotia, Ontario, Prince Edward Island and Saskatchewan. } \\
\text { qUsed to supplement the package code information obtained from the Drug Product Database. }\end{array}$} \\
\hline
\end{tabular}


We considered the following factors to be potentially associated with drug shortages at the market level, based on previous studies $^{14-17}$ and our available data:

- market structure (branded manufacturers only, branded manufacturers and a single generic manufacturer, branded manufacturers and multiple generic manufacturers, biologic manufacturers, a single generic manufacturer only, and multiple generic manufacturers) at baseline, where baseline was defined as the first 30 days of the follow-up period;

- route of administration or dosage form (oral solid regular release, oral solid special release, injection, oral nonsolid, other route or form [such as topical cream or ointment, ophthalmic solution, inhalation solution, inhalation powder, transdermal patch or nasal spray]), in which injection, oral nonsolid and other route or form are more complex from a manufacturing viewpoint than oral solids; ${ }^{27,28}$

- essential medicines or not, which refer to "those that satisfy the priority health care needs of the population" ${ }^{\prime 29,30}$ and were defined using the list from a report of the Patented Medicine Prices Review Board; ${ }^{30}$

- proportion of DINs listed on formularies in at least 1 of the provinces (excluding Quebec); and

- Anatomic Therapeutic Chemical (ATC) classification. ${ }^{31}$

At the DIN level, we considered some additional factors, including DIN age (duration from when the DIN came to market to the start of follow-up), the number of provinces on formulary (the number of provincial formularies on which the DIN was listed weighted by the population size in each province), top 50 manufacturers (based on drug cost from public drug plans in Canada in 2017/18), ${ }^{32}$ manufacturer size (total number of DINs available in Canada) and type of manufacturers (proportion of branded DINs). Detailed definitions can be found in Appendix 2, available at www.cmajopen.ca/ content/8/3/E535/suppl/DC1.

\section{Statistical analysis}

We used logistic regression to model shortages. We modeled shortage duration using a zero-truncated negative binomial regression model because of its skewed data distribution (Appendix 3, available at www.cmajopen.ca/content/8/3/ E535/suppl/DC1), where the offset is the natural log of the follow-up time. Factors that were included in the final regression models were determined by their univariate analysis results $(p<0.2)$ and the Akaike information criteria. ${ }^{33}$ Owing to the differences in terms of drug shortages and the factors between generic DINs and branded DINs, we conducted the analyses for generic and branded DINs separately. We also conducted a subgroup analysis among DINs that were listed on provincial formularies by considering their listing price ${ }^{25}$ as an additional factor. We conducted sensitivity analyses by defining "market" by active ingredients, dosage form and route of administration. We conducted all the analyses using SAS version 9.4 (SAS Institute).

\section{Ethics approval}

Ethics approval was not required because our focus is on market-level data.

\section{Results}

\section{Shortage at the market level}

Our analysis consisted of 3470 markets (9472 DINs, flow diagram in Appendix 4, Supplementary Figure 1, available at www.cmajopen.ca/content/8/3/E535/suppl/DC1). About $13.3 \%$ of markets $(n=462)$ were reported in shortage, and the average number of days in shortage was 136.6 (standard deviation [SD] 149.2) during our study period (Table 2; Appendix 4, Supplementary Table 1). Markets with a single generic manufacturer, oral nonsolid route or form, other complex route or form, or for sensory organs had a higher probability of being in shortage. More description is in Appendix 4.

The multivariable logistic regression results (Table 3 ) show that compared with markets with branded manufacturers and a single generic manufacturer, markets with a single generic manufacturer were more likely to be in shortage (odds ratio $[\mathrm{OR}] 1.99,95 \%$ confidence interval [CI] 1.28 to 3.11 ), whereas markets with multiple generic manufacturers with or without branded manufacturers were $87 \%$ or $43 \%$ less likely to be in shortage, respectively, during our study period. Markets with oral nonsolid route or form were $66 \%$ more likely to be in shortage than those with oral solid regular release route or form. The markets with a higher proportion of DINs on formularies were more likely to be in shortage (OR 1.03, 95\% CI 1.00 to 1.05 per $10 \%$ increase). The sensory organ ATC class was more likely to be in shortage than all other ATC classes except the class of antiparasitic products, insecticides and repellents. The results of pairwise comparisons are also presented in Appendix 5, available at www.cmajopen.ca/ content/8/3/E535/suppl/DC1.

Using a different definition of "market" in the sensitivity analysis, our results were similar except that markets with injection $(p=0.06)$ and other complex route or form $(p<0.01)$ were also more likely to be in shortage than those with oral solid regular release route or form, and that the odds of being in shortage were not different between the sensory organ ATC class and several other classes (Appendix 6, available at www.cmajopen.ca/content/8/3/E535/suppl/DC1).

\section{Shortage at the DIN level}

Among all 9472 DINs (2322 branded DINs, 6527 generic DINs and 623 biologic DINs), 2212 (23.4\%) were reported in shortage and their average number of days in shortage was 155.3 (SD 146.2). Generic DINs had a higher probability of being in shortage and having a longer shortage duration than branded DINs $(26.5 \%$ v. $18.3 \%$ in shortage $[p<0.01]$ and 167.6 [SD 149.1] v. 99.9 [SD 111.7] days [ $p<0.01$ ]; (Table 2; Appendix 4, Supplementary Table 1).

Table 4 presents the factors associated with shortage at the DIN level. For both branded and generic DINs, DINs in the markets with branded manufacturers and a single generic manufacturer were significantly more likely to be in shortage than DINs in other market structures. The DINs with older age were more likely to be in shortage. DINs for sensory organs were more likely to be in shortage than DINs for most of other ATC classes. However, branded 
Table 2: Markets and DINs in drug shortage and shortage duration

\begin{tabular}{|c|c|c|c|c|c|c|c|c|c|}
\hline \multirow[b]{2}{*}{ Variable } & \multicolumn{3}{|c|}{ Markets } & \multicolumn{3}{|c|}{ Branded DINs } & \multicolumn{3}{|c|}{ Generic DINs } \\
\hline & Total, $n$ & $\begin{array}{c}\text { Markets in } \\
\text { shortage, } \\
n(\%)\end{array}$ & $\begin{array}{l}\text { Shortage } \\
\text { duration, } \\
\text { mean days } \\
\pm \text { SD }\end{array}$ & Total, $n$ & $\begin{array}{c}\text { DINs in } \\
\text { shortage } \\
n(\%)\end{array}$ & $\begin{array}{l}\text { Shortage } \\
\text { duration, }{ }^{*} \\
\text { mean days } \\
\pm \text { SD }\end{array}$ & $\begin{array}{c}\text { Total, } \\
n\end{array}$ & $\begin{array}{c}\text { DINs in } \\
\text { shortage } \\
n(\%)\end{array}$ & $\begin{array}{l}\text { Shortage } \\
\text { duration, }{ }^{*} \\
\text { mean days } \\
\pm \text { SD }\end{array}$ \\
\hline All & 3470 & $\begin{array}{c}462 \\
(13.3)\end{array}$ & $\begin{array}{c}136.6 \\
\pm 149.2\end{array}$ & 2322 & $\begin{array}{c}426 \\
(18.3)\end{array}$ & $\begin{array}{c}99.9 \\
\pm 111.7\end{array}$ & 6527 & $\begin{array}{c}1730 \\
(26.5)\end{array}$ & $\begin{array}{c}167.6 \\
\pm 149.1\end{array}$ \\
\hline \multicolumn{10}{|l|}{ Market structure } \\
\hline$B$ and $G$ single & 208 & $\begin{array}{c}31 \\
(14.9)\end{array}$ & $\begin{array}{c}134.5 \\
\pm 131.2 \\
\end{array}$ & 235 & $\begin{array}{c}64 \\
(27.2)\end{array}$ & $\begin{array}{c}120.4 \\
\pm 124.7\end{array}$ & 214 & $\begin{array}{c}73 \\
(34.1)\end{array}$ & $\begin{array}{c}163.2 \\
\pm 160.9 \\
\end{array}$ \\
\hline B and G multiple & 620 & $\begin{array}{c}13 \\
(2.1)\end{array}$ & $\begin{array}{c}126.5 \\
\pm 142.3\end{array}$ & 681 & $\begin{array}{c}131 \\
(19.2)\end{array}$ & $\begin{array}{c}100.0 \\
\pm 109.9\end{array}$ & 4423 & $\begin{array}{c}1169 \\
(26.4)\end{array}$ & $\begin{array}{c}162.5 \\
\pm 144.9\end{array}$ \\
\hline G single & 454 & $\begin{array}{c}124 \\
(27.3)\end{array}$ & $\begin{array}{c}187.2 \\
\pm 169.2\end{array}$ & & & & 464 & $\begin{array}{c}127 \\
(27.4)\end{array}$ & $\begin{array}{c}188.2 \\
\pm 169.3\end{array}$ \\
\hline G multiple & 387 & $\begin{array}{c}36 \\
(9.3)\end{array}$ & $\begin{array}{c}130.0 \\
\pm 158.1\end{array}$ & & & & 1426 & $\begin{array}{c}361 \\
(25.3)\end{array}$ & $\begin{array}{c}177.9 \\
\pm 152.2\end{array}$ \\
\hline $\mathrm{BIO}$ & 484 & $\begin{array}{c}49 \\
(10.1)\end{array}$ & $\begin{array}{c}192.1 \\
\pm 184.6\end{array}$ & & & & & & \\
\hline B only & 1317 & $\begin{array}{c}209 \\
(15.9)\end{array}$ & $\begin{array}{c}95.6 \\
\pm 112.7\end{array}$ & 1406 & $\begin{array}{c}231 \\
(16.4)\end{array}$ & $\begin{array}{c}94.1 \\
\pm 108.7\end{array}$ & & & \\
\hline \multicolumn{10}{|l|}{ Route of administration or form } \\
\hline Injection & 991 & $\begin{array}{c}119 \\
(12.0)\end{array}$ & $\begin{array}{c}168.5 \\
\pm 170.3\end{array}$ & 323 & $\begin{array}{c}59 \\
(18.3)\end{array}$ & $\begin{array}{c}105.3 \\
\pm 108.1\end{array}$ & 640 & $\begin{array}{c}151 \\
(23.6)\end{array}$ & $\begin{array}{c}181.8 \\
\pm 163.1\end{array}$ \\
\hline Oral nonsolid & 189 & $\begin{array}{c}44 \\
(23.3)\end{array}$ & $\begin{array}{c}159.4 \\
\pm 170.8\end{array}$ & 123 & $\begin{array}{c}23 \\
(18.7)\end{array}$ & $\begin{array}{c}108.6 \\
\pm 123.2\end{array}$ & 134 & $\begin{array}{c}40 \\
(29.9)\end{array}$ & $\begin{array}{c}188.4 \\
\pm 164.7\end{array}$ \\
\hline Oral solid regular release & 1513 & $\begin{array}{c}154 \\
(10.2)\end{array}$ & $\begin{array}{c}132.6 \\
\pm 149.8\end{array}$ & 1195 & $\begin{array}{c}198 \\
(16.6)\end{array}$ & $\begin{array}{c}104.3 \\
\pm 119.2\end{array}$ & 4789 & $\begin{array}{c}1239 \\
(25.9)\end{array}$ & $\begin{array}{c}165.3 \\
\pm 145.7\end{array}$ \\
\hline Oral solid special release & 238 & $\begin{array}{c}25 \\
(10.5)\end{array}$ & $\begin{array}{c}84.0 \\
\pm 108.8\end{array}$ & 254 & $\begin{array}{c}39 \\
(15.4)\end{array}$ & $\begin{array}{c}75.2 \\
\pm 108.3\end{array}$ & 526 & $\begin{array}{c}144 \\
(27.4)\end{array}$ & $\begin{array}{c}179.6 \\
\pm 160.0\end{array}$ \\
\hline Other & 539 & $\begin{array}{c}120 \\
(22.3)\end{array}$ & $\begin{array}{c}112.5 \\
\pm 115.1\end{array}$ & 427 & $\begin{array}{c}107 \\
(25.1)\end{array}$ & $\begin{array}{c}95.8 \\
\pm 97.9\end{array}$ & 438 & $\begin{array}{c}156 \\
(35.6)\end{array}$ & $\begin{array}{c}156.0 \\
\pm 147.4\end{array}$ \\
\hline \multicolumn{10}{|l|}{ Essential medicine } \\
\hline No & 2981 & $\begin{array}{c}388 \\
(13.0)\end{array}$ & $\begin{array}{c}136.5 \\
\pm 149.0\end{array}$ & 1945 & $\begin{array}{c}361 \\
(18.6)\end{array}$ & $\begin{array}{c}103.3 \\
\pm 114.7\end{array}$ & 4923 & $\begin{array}{c}1277 \\
(25.9)\end{array}$ & $\begin{array}{c}167.5 \\
\pm 149.6\end{array}$ \\
\hline Yes & 489 & $\begin{array}{c}74 \\
(15.1)\end{array}$ & $\begin{array}{c}137.2 \\
\pm 151.1\end{array}$ & 377 & $\begin{array}{c}65 \\
(17.2)\end{array}$ & $\begin{array}{c}80.9 \\
\pm 91.5\end{array}$ & 1604 & $\begin{array}{c}453 \\
(28.2)\end{array}$ & $\begin{array}{c}167.9 \\
\pm 147.9\end{array}$ \\
\hline \multicolumn{10}{|l|}{ On formulary† } \\
\hline No & 878 & $\begin{array}{c}107 \\
(12.2)\end{array}$ & $\begin{array}{c}153.6 \\
\pm 168.0\end{array}$ & 512 & $\begin{array}{c}83 \\
(16.2)\end{array}$ & $\begin{array}{c}116.8 \\
\pm 131.7\end{array}$ & 1171 & $\begin{array}{c}222 \\
(19.0)\end{array}$ & $\begin{array}{c}154.8 \\
\pm 142.6\end{array}$ \\
\hline Yes & 2592 & $\begin{array}{c}355 \\
(13.7)\end{array}$ & $\begin{array}{c}131.5 \\
\pm 142.9\end{array}$ & 1810 & $\begin{array}{c}343 \\
(19.0)\end{array}$ & $\begin{array}{c}95.8 \\
\pm 106.1\end{array}$ & 5356 & $\begin{array}{c}1508 \\
(28.2)\end{array}$ & $\begin{array}{c}169.5 \\
\pm 150.0\end{array}$ \\
\hline \multicolumn{10}{|l|}{ DIN age, yr } \\
\hline$<3$ & & & & 250 & $\begin{array}{c}8 \\
(3.2)\end{array}$ & $\begin{array}{c}102.4 \\
\pm 105.7\end{array}$ & 1154 & $\begin{array}{c}193 \\
(16.7)\end{array}$ & $\begin{array}{c}183.1 \\
\pm 153.7\end{array}$ \\
\hline$\geq 3$ & & & & 2072 & $\begin{array}{c}418 \\
(20.2)\end{array}$ & $\begin{array}{c}99.8 \\
\pm 111.9\end{array}$ & 5373 & $\begin{array}{c}1537 \\
(28.6)\end{array}$ & $\begin{array}{c}165.7 \\
\pm 148.5 \\
\end{array}$ \\
\hline \multicolumn{10}{|l|}{ Top 50 manufacturers $\ddagger$} \\
\hline No & & & & 520 & $\begin{array}{c}85 \\
(16.3)\end{array}$ & $\begin{array}{c}119.2 \\
\pm 105.8\end{array}$ & 1942 & $\begin{array}{c}358 \\
(18.4)\end{array}$ & $\begin{array}{c}173.7 \\
\pm 149.1\end{array}$ \\
\hline Yes & & & & 1802 & $\begin{array}{c}341 \\
(18.9)\end{array}$ & $\begin{array}{c}95.1 \\
\pm 112.8\end{array}$ & 4585 & $\begin{array}{c}1372 \\
(29.9)\end{array}$ & $\begin{array}{c}166.1 \\
\pm 149.2\end{array}$ \\
\hline \multicolumn{10}{|l|}{ Manufacturer size§ } \\
\hline Small & & & & 731 & $\begin{array}{c}78 \\
(10.7)\end{array}$ & $\begin{array}{c}115.8 \\
\pm 111.3\end{array}$ & 322 & $\begin{array}{c}43 \\
(13.4)\end{array}$ & $\begin{array}{c}189.6 \\
\pm 186.8\end{array}$ \\
\hline Medium & & & & 682 & $\begin{array}{c}143 \\
(21.0)\end{array}$ & $\begin{array}{c}112.4 \\
\pm 128.3\end{array}$ & 636 & $\begin{array}{c}146 \\
(23.0)\end{array}$ & $\begin{array}{c}135.6 \\
\pm 119.5\end{array}$ \\
\hline Large & & & & 909 & $\begin{array}{c}205 \\
(22.6)\end{array}$ & $\begin{array}{c}85.0 \\
\pm 97.1\end{array}$ & 5569 & $\begin{array}{c}1541 \\
(27.7)\end{array}$ & $\begin{array}{c}170.1 \\
\pm 150.2\end{array}$ \\
\hline $\begin{array}{l}\text { Note: } \mathrm{B}=\text { branded manufactur } \\
\text { *Shortage duration among tho } \\
\text { †On provincial formulary in at I } \\
\text { †Top } 50 \text { manufacturers by dru } \\
\text { §Manufacturer size was define }\end{array}$ & $\begin{array}{l}\text { biologic } \\
\text { rtage. } \\
\text { the inclu } \\
\text { m public } \\
\text { total num }\end{array}$ & $\begin{array}{l}\text { nufacturer, D } \\
\text { d provinces. } \\
\text { g plans in Ca } \\
\text { of DINs. Sm }\end{array}$ & $\begin{array}{l}\text { Drug Identific } \\
\text { a in 2017/18. } \\
-40, \text { Medium }\end{array}$ & 99 & $\hat{x}=$ generi & & & & \\
\hline
\end{tabular}


Table 3: Association between drug shortage and factors and its duration at the market level

\begin{tabular}{|c|c|c|c|c|}
\hline \multirow[b]{2}{*}{ Parameter or level } & \multirow{2}{*}{$\begin{array}{c}\text { Shortage } \\
\text { OR } \\
(95 \% \mathrm{Cl})\end{array}$} & \multicolumn{3}{|c|}{ Shortage duration* } \\
\hline & & $\begin{array}{l}\text { Coefficient } \\
\text { (SE) }\end{array}$ & $p$ value & $\begin{array}{l}\text { Average marginal effect } \\
\qquad(95 \% \mathrm{Cl}) \ddagger\end{array}$ \\
\hline \multicolumn{5}{|l|}{ Market structure (Ref.: B and G single) } \\
\hline B and $G$ multiple & $0.13(0.06$ to 0.25$)$ & $-0.18(0.38)$ & 0.639 & $-23.5(-121$ to 80.6$)$ \\
\hline B only & $1.15(0.76$ to 1.76$)$ & $-0.17(0.23)$ & 0.465 & $-22.0(-104$ to 32.0$)$ \\
\hline G single & 1.99 (1.28 to 3.11$)$ & $0.51(0.24)$ & 0.034 & 95.9 (11.4 to 169.0$)$ \\
\hline G multiple & 0.57 (0.34 to 0.97$)$ & $-0.19(0.29)$ & 0.502 & $-25.1(-112$ to 51.0$)$ \\
\hline $\mathrm{BIO}$ & $1.13(0.65$ to 1.97$)$ & $0.34(0.32)$ & 0.283 & $58.2(-57.9$ to 167.4$)$ \\
\hline Overall $p$ value $\dagger$ & $<0.001$ & $<0.001$ & & \\
\hline \multicolumn{5}{|l|}{ Route of administration or form (Ref.: oral solid regular release) } \\
\hline Injection & $1.14(0.82$ to 1.59$)$ & $0.05(0.21)$ & 0.831 & $7.2(-58.2$ to 75.7$)$ \\
\hline Oral nonsolid & 1.66 (1.11 to 2.49$)$ & $0.27(0.21)$ & 0.204 & $47.1(-22.7$ to 130.1$)$ \\
\hline Oral solid special release & 1.05 (0.66 to 1.68$)$ & $0.04(0.27)$ & 0.896 & $5.6(-96.0$ to 150.1$)$ \\
\hline Other & $1.31(0.89$ to 1.91$)$ & $-0.01(0.21)$ & 0.942 & $-2.3(-65.7$ to 76.6$)$ \\
\hline Overall $p$ value $\dagger$ & 0.151 & 0.758 & & \\
\hline \multicolumn{5}{|l|}{ Proportion of DINs on formulary } \\
\hline Per $10 \%$ increase & $1.03(1.00$ to 1.05$)$ & $-0.02(0.01)$ & 0.071 & $-3.8(-8.3$ to 0.5$) \S$ \\
\hline \multicolumn{5}{|l|}{ Anatomic Therapeutic Chemical Classification (Ref.: sensory organs) } \\
\hline Alimentary tract and metabolism & $0.20(0.10$ to 0.38$)$ & $-0.40(0.35)$ & 0.255 & $-70.4(-210$ to 56.0$)$ \\
\hline Blood and blood-forming organs & $0.08(0.03$ to 0.22$)$ & $-0.64(0.56)$ & 0.258 & $-100(-262$ to 100.9$)$ \\
\hline Cardiovascular system & $0.51(0.28$ to 0.90$)$ & $-0.31(0.29)$ & 0.281 & $-57.5(-204$ to 56.1$)$ \\
\hline Dermatologicals & $0.36(0.20$ to 0.64$)$ & $-0.07(0.29)$ & 0.803 & $-14.7(-135$ to 108.8$)$ \\
\hline Genitourinary system and sex hormones & $0.55(0.31$ to 0.98$)$ & $-0.36(0.30)$ & 0.230 & $-64.2(-196$ to 46.1$)$ \\
\hline $\begin{array}{l}\text { Systemic hormonal preparations, excluding sex hormones } \\
\text { and insulins }\end{array}$ & $0.30(0.15$ to 0.59$)$ & $-0.41(0.38)$ & 0.287 & $-71.2(-216$ to 67.5$)$ \\
\hline Anti-infectives for systemic use & $0.43(0.25$ to 0.74$)$ & $-0.33(0.31)$ & 0.287 & $-59.7(-194$ to 51.9$)$ \\
\hline Antineoplastic and immunomodulating agents & $0.18(0.10$ to 0.34$)$ & $-0.53(0.37)$ & 0.148 & $-88.3(-232$ to 54.7$)$ \\
\hline Musculoskeletal system & $0.35(0.17$ to 0.73$)$ & $-0.01(0.37)$ & 0.970 & $-2.9(-155$ to 144.7$)$ \\
\hline Nervous system & $0.35(0.21$ to 0.59$)$ & $-0.23(0.28)$ & 0.399 & $-44.5(-170$ to 65.4$)$ \\
\hline Antiparasitic products, insecticides and repellents & 0.55 (0.10 to 2.89$)$ & $-1.03(0.85)$ & 0.225 & $-137(-282$ to -2.5$)$ \\
\hline Respiratory system & $0.58(0.34$ to 0.99$)$ & $-0.44(0.28)$ & 0.111 & $-75.8(-191$ to 12.6$)$ \\
\hline Various & $0.22(0.11$ to 0.47$)$ & $-0.18(0.44)$ & 0.676 & $-35.4(-189$ to 144.4$)$ \\
\hline Overall $p$ value $†$ & $<0.001$ & 0.955 & & \\
\hline \multicolumn{5}{|l|}{ Model fit statistics } \\
\hline C-statistic & 0.73 & & & \\
\hline AIC & 2487.90 & 5540.4 & & \\
\hline Log-likelihood & -1219.95 & -2745.2 & & \\
\hline \multicolumn{5}{|c|}{$\begin{array}{l}\text { Note: } \mathrm{AIC}=\text { Akaike information criteria, } \mathrm{B}=\text { branded manufacturer, } \mathrm{BIO}=\text { biologic manufacturer, } \mathrm{Cl}=\text { confidence interval, } \mathrm{DIN}=\text { Drug Identification Number, } \mathrm{G}=\text { generic } \\
\text { manufacturer, OR = odds ratio, Ref. = reference category ( } 0 \text { or } 1 \text { as appropriate), } \mathrm{SE}=\text { standard error. } \\
\text { * Results were based on truncated negative binomial regression models among markets in shortage. } \\
\text { tBased on type III Wald Test for shortage and type III likelihood ratio test for shortage duration. } \\
\text { †The average marginal effect of a variable was evaluated as the average of predicted differences (from the reference group) at observed values of covariates for each } \\
\text { observation; } 95 \% \text { Cl were the bootstrap confidence intervals based on } 2000 \text { bootstrap samples. } \\
\text { §For an increase from } 80 \% \text { to } 90 \% \text {. }\end{array}$} \\
\hline
\end{tabular}

DINs from branded manufacturers and top 50 manufacturers were less likely to be in shortage than those from other manufacturer types. Generic DINs from large or medium manufacturers irrespective of whether they were in the top
50 manufacturers, were all more likely to be in shortage than small manufacturers.

Essential medicines were marginally significantly associated with higher odds of being in shortage for generic DINs 
Table 4: Association between drug shortage and factors at the DIN level

\begin{tabular}{|c|c|c|}
\hline Parameter or level & $\begin{array}{l}\text { Branded DINs } \\
\text { OR }(95 \% \mathrm{CI})\end{array}$ & $\begin{array}{l}\text { Generic DINs } \\
\text { OR }(95 \% \mathrm{CI})\end{array}$ \\
\hline \multicolumn{3}{|l|}{ Market structure (Ref.: B and G single) } \\
\hline B and G multiple & 0.65 (0.45 to 0.94$)$ & $0.68(0.49$ to 0.93$)$ \\
\hline B only & $0.68(0.48$ to 0.95$)$ & \\
\hline G single & & $0.65(0.45$ to 0.93$)$ \\
\hline G multiple & & $0.62(0.45$ to 0.86$)$ \\
\hline Overall $p$ value* & 0.048 & 0.036 \\
\hline DIN age (every year increase) & $1.02(1.02$ to 1.03$)$ & \\
\hline \multicolumn{3}{|l|}{ DIN age, yr $($ Ref.: $<3)$} \\
\hline$\geq 3$ & & $1.85(1.55$ to 2.21$)$ \\
\hline \multicolumn{3}{|l|}{ Route of administration or form (Ref.: oral solid regular release) } \\
\hline Injection & $1.16(0.80$ to 1.70$)$ & 1.29 (1.00 to 1.66$)$ \\
\hline Oral nonsolid & $1.12(0.67$ to 1.89$)$ & 1.09 (0.73 to 1.65$)$ \\
\hline Oral solid special release & $0.87(0.59$ to 1.28$)$ & $1.17(0.94$ to 1.45$)$ \\
\hline Other & $1.28(0.84$ to 1.94$)$ & $1.23(0.87$ to 1.72$)$ \\
\hline Overall $p$ value & 0.603 & 0.165 \\
\hline \multicolumn{3}{|c|}{ Interaction of manufacturer type and top 50 manufacturer (Ref.: branded = yes, top $50=$ yes) } \\
\hline Branded $=$ no, top $50=$ no & $3.22(1.91$ to 5.44$)$ & \\
\hline Branded $=$ no, top $50=$ yes & $2.23(1.50$ to 3.31$)$ & \\
\hline Branded $=$ yes, top $50=$ no & $1.59(1.13$ to 2.25$)$ & \\
\hline Overall $p$ value ${ }^{*}$ & $<0.001$ & \\
\hline \multicolumn{3}{|l|}{ Interaction of manufacturer size and top 50 manufacturer (Ref.: small) } \\
\hline Large, top $50=$ no & & $1.82(1.25$ to 2.64$)$ \\
\hline Large, top $50=$ yes & & 2.40 (1.71 to 3.38$)$ \\
\hline Medium, top $50=$ no & & 2.16 (1.45 to 3.23$)$ \\
\hline Medium, top $50=$ yes & & 2.41 (1.39 to 4.17$)$ \\
\hline Overall $p$ value* & & $<0.001$ \\
\hline \multicolumn{3}{|l|}{ Essential medicine (Ref.: no) } \\
\hline Yes & & $1.13(0.99$ to 1.30$)$ \\
\hline Number of provinces on formulary (weighted) & & $1.09(1.07$ to 1.11$)$ \\
\hline \multicolumn{3}{|l|}{ Anatomic Therapeutic Chemical Classification (Ref.: sensory organs) } \\
\hline Alimentary tract and metabolism & $0.40(0.20$ to 0.81$)$ & $0.30(0.18$ to 0.50$)$ \\
\hline Blood and blood-forming organs & $0.35(0.14$ to 0.86$)$ & $0.12(0.05$ to 0.30$)$ \\
\hline Cardiovascular system & $0.57(0.30$ to 1.10$)$ & $0.35(0.22$ to 0.56$)$ \\
\hline Dermatologicals & $0.51(0.28$ to 0.94$)$ & $0.37(0.22$ to 0.64$)$ \\
\hline Genitourinary system and sex hormones & $0.45(0.23$ to 0.85$)$ & $0.42(0.25$ to 0.71$)$ \\
\hline Systemic hormonal preparations, excluding sex hormones and insulins & $0.22(0.10$ to 0.51$)$ & $0.35(0.18$ to 0.70$)$ \\
\hline Anti-infectives for systemic use & $0.31(0.15$ to 0.62$)$ & $0.41(0.25$ to 0.67$)$ \\
\hline Antineoplastic and immunomodulating agents & $0.22(0.11$ to 0.45$)$ & $0.36(0.21$ to 0.63$)$ \\
\hline Musculoskeletal system & $0.63(0.27$ to 1.43$)$ & $0.27(0.16$ to 0.45$)$ \\
\hline Nervous system & $0.43(0.23$ to 0.79$)$ & $0.40(0.25$ to 0.64$)$ \\
\hline Antiparasitic products, insecticides and repellents & $0.60(0.10$ to 3.60$)$ & $0.28(0.08$ to 0.92$)$ \\
\hline Respiratory system & $0.64(0.34$ to 1.21$)$ & $0.48(0.29$ to 0.81$)$ \\
\hline Various & 0.30 (0.09 to 0.97$)$ & $0.46(0.17$ to 1.23$)$ \\
\hline Overall $p$ value ${ }^{*}$ & 0.004 & $<0.001$ \\
\hline \multicolumn{3}{|l|}{ Model fit statistics } \\
\hline C-statistic & 0.68 & 0.64 \\
\hline $\mathrm{AIC}$ & 2126.38 & 7278.45 \\
\hline Log-likelihood & -1038.19 & -3611.23 \\
\hline \multicolumn{3}{|c|}{$\begin{array}{l}\text { Note: } \mathrm{AIC}=\text { Akaike information criteria, } \mathrm{B}=\text { branded manufacturer, } \mathrm{Cl}=\text { confidence interval, } \mathrm{DIN}=\text { Drug Identification Number, } \mathrm{G}=\text { generic } \\
\text { manufacturer, OR = odds ratio, Ref.= reference category. } \\
\text { *Based on type III Wald Test. }\end{array}$} \\
\hline
\end{tabular}


but not for branded DINs. Generic DINs listed on more provincial formularies were more likely to be in shortage. The subgroup analysis among DINs being listed on formularies shows that a lower listing price was marginally significantly associated with the shortage of branded DINs $(p=0.06)$ but not with the shortage of generic DINs (Appendix 7, available at www.cmajopen.ca/content/8/3/E535/suppl/DC1).

\section{Shortage duration among markets and DINs}

At the market level, markets with a single generic manufacturer tended to have a longer shortage duration (OR 95.9, 95\% CI 11.4 to 169.0 more days) than those with branded manufacturers and a single generic manufacturer (Table 3). At the DIN level, disruption of the manufacturer, shortage of ingredients, delay in shipping not being the shortage reason, business reason, older DIN age, not being listed on formulary and smaller manufacturer size were associated with a longer shortage duration for branded DINs (Table 5). For generic DINs, disruption of the manufacturer, demand increase not being the shortage reason, business reason and being in sensory organs ATC class were associated with a longer shortage duration.

\section{Interpretation}

Our main finding is that markets with a single generic manufacturer were the most vulnerable to shortage during our study period. This did not occur for markets with a single branded manufacturer, suggesting that markets with a single supplier and relatively lower profit margins (related to the lower reimbursement price for generic drugs ${ }^{34,35}$ ) may lead to shortages. Markets with complex routes or formulations were more susceptible to shortage, although generic pricing regulations have allowed a higher reimbursement price for non-oral solid drugs. ${ }^{34,35}$ Markets for sensory organs ATC class or with more demand from public insurance programs were more likely to be in shortage.

At the DIN level, when generic DINs or branded DINs were in the markets with branded manufacturers and a single generic manufacturer, they were the most likely to be in shortage. This might be driven by the combined impact of the generic competition, lower reimbursement price from public insurance programs $\mathrm{s}^{34,35}$ and small market size that can accommodate only a single generic entrant. In addition, the newer branded or generic DINs were less likely to be in shortage. Possible reasons included the restriction of price increases for drugs by provincial governments, ${ }^{36}$ the pan-Canadian tiered pricing framework for new generic drugs implemented on Apr. 1, 2017,,$^{34,35}$ large loss of market share for older branded DINs after generic entry $y^{37-39}$ or that manufacturers might pay more attention to the supply of the relatively newer products.

Some of our study findings are consistent with those from the US Government Accountability Office, which identified factors (a decline in the number of suppliers and drugs with sales of a generic version) that were strongly associated with shortages of sterile injectable anti-infective and cardiovascular drugs in 2012-2014 in the US. ${ }^{14}$ Dave and colleagues found that special formulations, such as solutions and extended-release capsules, were associated with higher risks of generic drug shortages in the US. ${ }^{17}$ Donelle and colleagues were the first to assess the drug shortage problem using the Drug Shortages Canada database. ${ }^{21}$ However, their analyses were based on the data reported between 2010 and 2017 (before the mandatory reporting), which were incomplete.

Compared with previous studies, one of our study's strengths is that we focused on shortages at the market level rather than at the DIN or drug product-level only. This perspective is more relevant as it speaks to real shortage scenarios as opposed to a situation in which one manufacturer is not supplying but others are. In addition, we considered all active drugs in Canada that can be used in both community and hospital settings instead of focusing on generic drugs for outpatient use only ${ }^{17}$ or drugs for certain diseases. ${ }^{14-16}$ The subgroup analysis among DINs listed on provincial formularies represented those used mainly in community settings (dispensed in community pharmacies).

\section{Limitations}

One of our study limitations is that we could evaluate the association between drug price and drug shortage only among DINs listed on formularies because of a lack of price data for all DINs. Although lower prices have been found to be associated with shortages of generic drugs, ${ }^{15,17}$ we did not find such an association in generic DINs but a marginally significant association among branded DINs. Prices for branded and generic drugs are typically regulated by different pricing policies. In Canada, prices of generic drugs covered under publicly funded insurance programs have been regulated by the pan-Canadian tiered pricing framework or by provincial price-cap policies, ${ }^{34,35}$ under which generic prices are capped at specified percentages of the associated branded drug's price. The percentages vary from $10 \%$ to $35 \%$ for existing generic drugs and $25 \%$ to $85 \%$ for new generic drugs (since Apr. 1, 2017), depending on the number of suppliers. ${ }^{34,35}$ The prices of patented branded drugs are regulated by the Patented Medicine Prices Review Board, ${ }^{40}$ assessed for costeffectiveness by the Canadian Agency for Drugs and Technologies in Health ${ }^{41}$ and negotiated by the pan-Canadian Pharmaceutical Alliance. ${ }^{42}$ Owing to the fact that the price varies widely between the branded and generic DINs, we were not able to consider price at the market level.

In addition, we did not have utilization data for each DIN. To mitigate this limitation, we considered the formulary listing in different provinces, market structure and essential medicines, which might indicate different levels of utilization. Another limitation is regarding the main shortage reason options given on the Drug Shortages Canada website. These reasons might not be mutually exclusive; e.g., "shortage of an active ingredient" or "shortage of an inactive ingredient or component" could overlap with "demand increase for the drug." In addition, the stated reasons are simply those that the manufacturers chose to report, but they may or may not reflect what is actually happening. 
Research

Table 5: Association between duration of drug shortage and factors at the DIN level among those in shortage

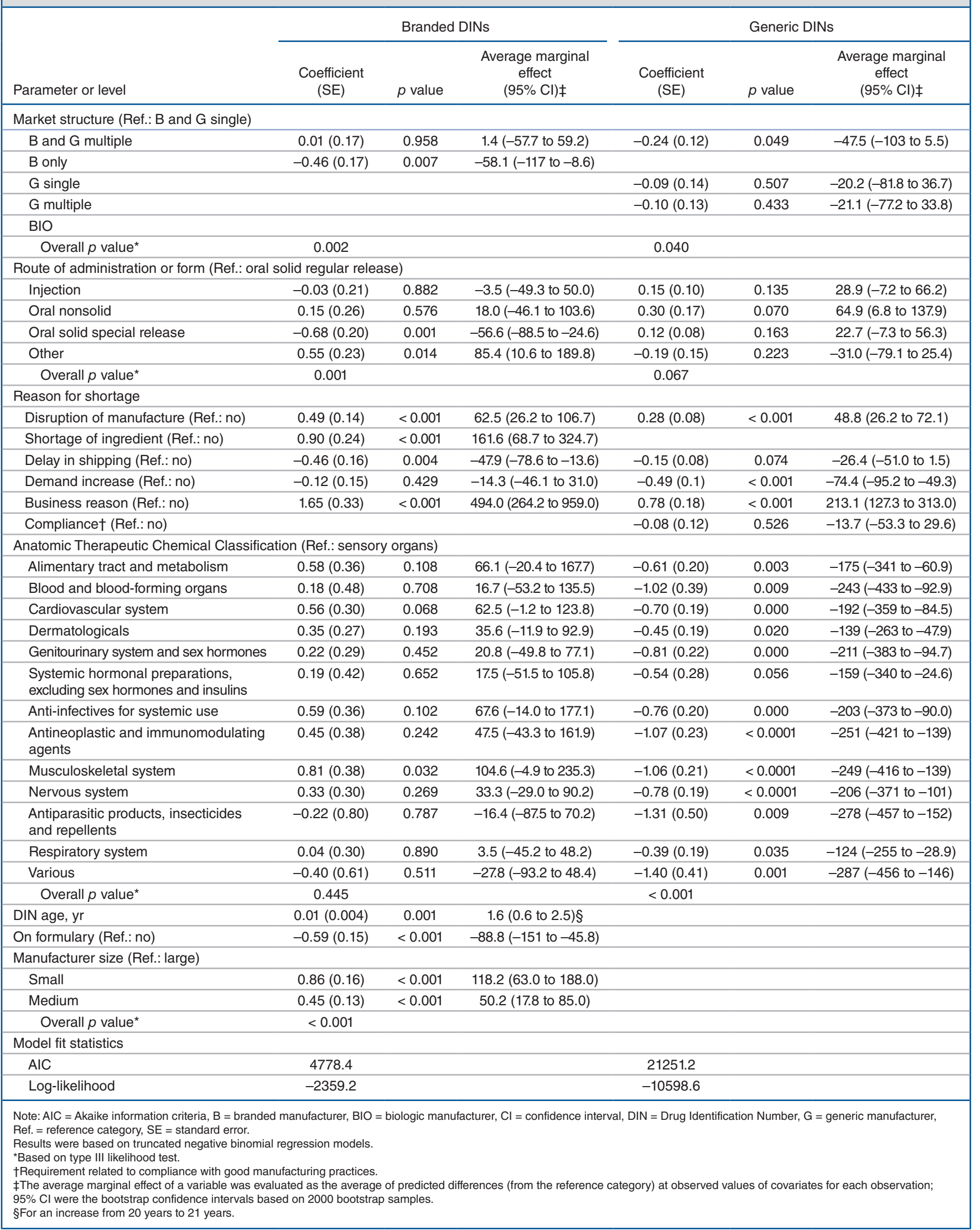




\section{Conclusion}

Markets with a single generic manufacturer, oral nonsolid route or form, larger proportion of drugs on provincial formularies and in sensory organs ATC class were more likely to be in shortage. Policy-makers trying to balance costcontainment with security of drug supply should pay extra attention to markets with relatively tight profit margins and that are under pressure of price-capping policies, which may result in a market with a single generic supplier. In addition, they should be vigilant in monitoring markets with complex manufacturing processes, with higher demand from public insurance programs or those that are in certain ATC classes.

\section{References}

1. Therrien A. EpiPen shortage: chemists told to quiz parents on children's need. British Broadcasting Corporation 2018 Oct. 17. Available: www.bbc.com/news/ health-45901529 (accessed 2018 Nov. 2).

2. EpiPen shortage is critical - and not easy to fix. Globe and Mail [Toronto]. Available: www.theglobeandmail.com/opinion/article-epipen-shortage-is -critical-and-not-easy-to-fix/ (accessed 2018 Nov. 2).

3. Lundy J. EpiPen shortage persists for some. Duluth (MN): Duluth News Tribune and Forum Communications Company; 2018. Available: www. duluthnewstribune.com/business/healthcare/4503411-epipen-shortage -persists-some (accessed 2018 Dec. 21).

4. Opioid shortages leave US hospitals scrambling. CNN 2018 Mar. 19. Available: www.cnn.com/2018/03/19/health/hospital-opioid-shortage-partner/index.html (accessed 2018 Nov. 2)

5. Doward J. Cost of lifesaving heroin withdrawal drug soars by $700 \%$. The Guardian 2018 Sept. 29. Available: www.theguardian.com/politics/2018/ sep/29/heroin-withdrawal-generic-drug-price-hike (accessed 2018 Dec. 21).

6. Fairclough I. Fentanyl's spread likely linked to heroin shortage: report. The Chronicle Herald 2018 Dec. 5, updated 2019 Apr. 24. Available: www.thechronicle herald.ca/news/local/fentanyls-spread-likely-linked-to-heroin-shortage-report -265769/ (accessed 2018 Dec. 21).

7. Crowe K. It's not just the EpiPen. Canada had 25 new drug shortages this week alone. CBC News 2018 Sept. 8. Available: www.cbc.ca/news/health/ second-opinion-drug-shortages180908-1.4815355 (accessed 2018 Sept. 15).

8. Ventola CL. The drug shortage crisis in the United States: causes, impacts, and management strategies. P\&T 2011;36:740-57.

9. Vail E, Gershengorn HB, Hua M, et al. Association between US norepinephrine shortage and mortality among patients with septic shock. 7AMA 2017;317:1433-42.

10. Bruera E. Parenteral opioid shortage - treating pain during the opioidoverdose epidemic. N Engl 7 Med 2018;379:601-3.

11. FDA drug shortages: current and resolved drug shortages and discontinuations reported to FDA. Silver Spring (MD): US Food and Drug Administration. Available: www.accessdata.fda.gov/scripts/drugshortages/ (accessed 2018 Jan. 17).

12. Drug shortages list: current drug shortage bulletins. Bethesda (MD): American Society of Health-System Pharmacists. Available: www.ashp.org/drug-shortages/ current-shortages/drug-shortages-list?page=CurrentShortages (accessed 2018 Jan. 17).

13. Woodcock J, Wosinska M. Economic and technological drivers of generic sterile injectable drug shortages. Clin Pharmacol Ther 2013;93:170-6.

14. Drug shortages: Certain factors are strongly associated with this persistent public health challenge. Report No GAO-16-595. Washington (DC): U.S. Government Accountability Office; 2016. Available: www.gao.gov/products/ GAO-16-595 (accessed 2018 Nov. 6).

15. Yurukoglu A, Liebman E, Ridley DB. The role of government reimbursement in drug shortages. Am Econ 7 Econ Policy 2017;9:348-82. doi: 10.1257/ pol.20160035

16. Ridley DB, Bei X, Liebman EB. No shot: US vaccine prices and shortages. Health Aff (Millwood) 2016;35:235-41.

17. Dave CV, Pawar A, Fox ER, et al. Predictors of drug shortages and association with generic drug prices: a retrospective cohort study. Value Health 2018;21:1286-90.

18. Gagnon M-A. Drug shortages: searching for a cure. Healtbc Policy 2012;7:10-7.

19. Duffin J. Canadian drug shortage: recent history of a mystery. CMAJ 2012;184:1000.

20. Progress in addressing drug shortages. Ottawa: Health Canada; modified 2017 Apr. 11. Available: www.hc-sc.gc.ca/dhp-mps/prodpharma/shortages-penuries/ progress-progres-eng.php (accessed 2016 Nov. 23).

21. Donelle J, Duffin J, Pipitone J, et al. Assessing Canada's drug shortage problem. Commentary no 515. Toronto: C.D. Howe Institute; 2018.

22. Drug shortages homepage. Available: www.drugshortagescanada.ca/ (accessed 2018 Oct. 1)
23. Mandatory reporting of drugs shortages and discontinuances on track for spring 2017 implementation [news release]. Ottawa: Health Canada; 2016. Available: www.canada.ca/en/health-canada/news/2016/06/mandatory -reporting-of-drugs-shortages-and-discontinuances-on-track-for-spring-2017 -implementation.html (accessed 2016 Nov. 23).

24. What is the DPD data extract?: Drug Product Database (DPD). Ottawa: Health Canada; modified 2020 Jul. 10. Available: www.canada.ca/en/health -canada/services/drugs-health-products/drug-products/drug-product-database/ what-data-extract-drug-product-database.html (accessed 2018 Dec. 12).

25. National Prescription Drug Utilization Information System metadata. Ottawa: Canadian Institute for Health Information. Available: www.cihi.ca/ en/national-prescription-drug-utilization-information-system-metadata (accessed 2018 Jan. 30).

26. PharmaClik [login page]. McKesson Canada. Available: www.mckesson.ca/ customer-login (accessed 2018 Oct. 10).

27. Danzon PM, Furukawa MF. Cross-national evidence on generic pharmaceuticals: pharmacy vs. physician-driven markets. Report no 17226. Cambridge (MA): National Bureau of Economic Research; 2011. Available: www.nber.org/ papers/w17226 (accessed 2016 Mar. 4).

28. The Multi-Stakeholder Steering Committee on Drug Shortages: Preventing drug shortages - Identifying risks and strategies to address manufacturing-related drug shortages in Canada. Drug Shortages Canada; 2017. Available: www.drugshortagescanada.ca/files/MSSC_Causes_and_Prevention_2017.pdf (accessed 2020 Jan. 2).

29. Essential medicines and health products. Geneva: World Health Organization. Available: www.who.int/medicines/services/essmedicines_def/en/ (accessed 2020 Mar. 17).

30. Alignment among public formularies in Canada - Part 1: General overview. Ottawa: Patented Medicine Prices Review Board; 2017, modified 2019 Mar. 5. Available: www.pmprb-cepmb.gc.ca/view.asp?ccid=1327\&lang=en (accessed 2018 Sept. 13).

31. 2. Anatomical Therapeutic Chemical (ATC) classification. In: Essential Medicines and Health Products. Geneva: World Health Organization. Available: www. who.int/medicines/regulation/medicines-safety/toolkit_atc/en/ (accessed 2020 Mar. 17).

32. CompassRx, 5th edition: Annual Public Drug Plan Expenditure Report, 2017/18. Cat no H79-6E-PDF. Ottawa: Patented Medicine Prices Review Board; 2019. Available: www.pmprb-cepmb.gc.ca/view $\cdot$ asp? ccid $=1474 \&$ lang=en\#a23 (accessed 2019 Oct. 23).

33. Akaike H. A new look at the statistical model identification. IEEE Trans Automat Contr 1974;19:716-23. doi: 10.1109/TAC.1974.1100705.

34. National Prescription Drug Utilization Information System - Plan information: summary of changes. Ottawa: Canadian Institute for Health Information; 2018. Available: https://secure.cihi.ca/free_products/Summary-of-changes-comparison -2018-EN02cg.pdf (accessed 2018 Sept. 10).

35. Pan-Canadian Generics: Pan-Canadian tiered pricing framework. Regina (SK): Drug Plan and Extended Benefits Branch, Government of Saskatchewan. Available: http://formulary.drugplan.ehealthsask.ca/PanCanadianGenerics (accessed 2018 Sept. 10).

36. Shajarizadeh A, Hollis A. Price-cap regulation, uncertainty and the price evolution of new pharmaceuticals. Health Econ 2015;24:966-77.

37. Hollis A. The importance of being first: evidence from Canadian generic pharmaceuticals. Health Econ 2002;11:723-34.

38. Yu Y, Gupta S. Pioneering advantage in generic drug competition. Int 7 Pharm Healthc Mark 2014;8:1-51. doi: 10.2139/ssrn.925346.

39. Grabowski H, Long G, Mortimer R, et al. Updated trends in US brand-name and generic drug competition. 7 Med Econ 2016;19:836-44.

40. Regulatory process. Ottawa: Patented Medicine Prices Review Board; modified 2018 Oct. 9. Available: www.pmprb-cepmb.gc.ca/en/regulating-prices/regulatory -process (accessed 2018 Jan. 26).

41. About CADTH. Ottawa: Canadian Agency for Drugs and Technologies in Health. Available: www.cadth.ca/about-cadth (accessed 2017 Mar. 15).

42. The pan-Canadian Pharmaceutical Alliance. Canada's Premiers. Ottawa: Council of the Federation Secretariat. Available: www.canadaspremiers.ca/ pan-canadian-pharmaceutical-alliance-archives/ (accessed 2018 Jan. 23).

Affiliations: Centre for Health Evaluation and Outcome Sciences (Zhang, Guh, Sun, Lynd, Anis), St. Paul's Hospital; School of Population and Public Health (Zhang, Anis) and Faculty of Pharmaceutical Sciences (Lynd), University of British Columbia, Vancouver, BC; Department of Economics (Hollis), University of Calgary, Calgary, Alta.; Leslie Dan Faculty of Pharmacy (Grootendorst), University of Toronto, Toronto, Ont.

Contributors: Wei Zhang, Aslam Anis, Larry Lynd, Aidan Hollis and Paul Grootendorst substantially contributed to the conception, study design, and interpretation of the results. Daphne Guh and Huiying Sun linked all data from the sources, conducted the data analyses and interpreted the data. Wei Zhang drafted the manuscript and all other authors revised it critically for important intellectual content. All authors 
approved the final version of the manuscript and agreed to be accountable for all aspects of the work in ensuring that questions related to accuracy or integrity of any part of the work are appropriately investigated and resolved.

Funding: This study was funded by the Canadian Institutes of Health Research Project Grant (PJT-153280).

Data sharing: The complete dataset used in our study is not available to others. However, data on drug shortages may be extracted from the Drug Shortages Canada website (www.drugshortagescanada.ca). The Drug Product Database of Health Canada can be accessed from www.canada.ca/en/ health-canada/services/drugs-health-products/drug-products/drug-product -database/what-data-extract-drug-product-database.html. Formulary data can be accessed by request from the Canadian Institute for Health Information (www.cihi.ca/en/national-prescription-drug-utilization-information -system-metadata). More detailed data access information can be found in Appendix 1.

Acknowledgement: We acknowledge that a collaborator, Colleen Brady, provided access to the PharmaClik database to facilitate extraction of package size associated with each DIN.

Supplemental information: For reviewer comments and the original submission of this manuscript, please see www.cmajopen.ca/content/8/3/ E535/suppl/DC1. 